\title{
APLIKASI WEBSITE BERBASIS HTML DAN JAVASCRIPT UNTUK MENYELESAIKAN FUNGSI INTEGRAL PADA MATA KULIAH KALKULUS
}

\author{
Selli Mariko* \\ Universitas Indraprasta PGRI. Jl. Nangka Raya No. 58 C, Jakarta Selatan 12530, Indonesia \\ * Corresponding Author. Email: sellimariko85@gmail.com \\ Received: 7 Desember 2018; Revised: 27 May 2019; Accepted: 18 Juni 2019
}

\begin{abstract}
Abstrak
Setiap mahasiswa yang mengambil jurusan seperti: MIPA, teknik, dan kedokteran pasti pada saat perkuliahan wajib mengambil mata kuliah kalkulus. Mata kuliah kalkulus dibahas dalam berbagai macam persamaan salah satunya adalah persamaan integral. Persamaan integral biasannya digunakan untuk melakukan pendekatan perhitungan pada kasus fisis teertentu, sehingga dapat dicari solusinya. Selain itu mengitung fungsi integral juga mempuyai tingkat kesulitan tinggi, karena dibutuhkan kecepatan dan ketelitian pada proses perhitungannya. Tujuan dari penelitian ini adalah menghasilkan sebuah produk penelitian berupa aplikasi untuk menghitung dan menyelesaikan fungsi integral. Jenis penelitian yang digunakan dalam penelitian ini adalah Research and Development. Sedangkan untuk mengembangkan aplikasi peneliti menggunakan bahasa Hypertext Markup Language (HTML) dan JavaScript. Sedangkan metode numerik sebagai dasar dalam membangun aplikasi ini adalah metode Simpson 1/3. Hasil penelitian ini adalah software dalam bentuk web aplikasi yang berfungsi untuk menghitung berbagai fungsi integral. Adapun keuntungan produk penelitan ini: (1) Dapat berjalan pada semua operating system; (2) Tidak perlu tambahan fitur installasi untuk membuka aplikasi produk penelitian; dan (3) Dapat berjalan pada semua tipe hardware (laptop, personal computer, dan smartphone).
\end{abstract}

Kata Kunci: Aplikasi web, integral, JavaScript, HTML

\section{WEB-BASED APPLICATION ON HTML AND JAVASCRIPT TO COMPLETE INTEGRAL FUNCTIONS IN CALCULUS LESSONS}

\begin{abstract}
Every student majoring in: MIPA, Engineering and Medicine is required to take calculus courses during college. In calculus subjects various kinds of equations are discussed, one of which is integral equations. Integral equations are usually used to approach calculations in certain physical cases, so that solutions can be found. In addition, calculating the integral function has a high level of difficulty, because it requires speed and accuracy in the calculation process. The type of research used in this study is Research and Development. To develop application, researchers use Hypertext Markup Language (HTML) and JavaScript languages. While the numerical method as the basis for building this appliacation is the Simpson 1/3 Method. The results of this study are software in the form of web applications that function to calculate various integral functions: 1. Can run on all operating systems; 2. No need for additional application features to open (just a web browser); 3. Can run on all types of hardware (laptops, computer personal and smartphones).
\end{abstract}

Keywords: Web-based aplications, integral, JavaScript, HTML

doi http://dx.doi.org/10.21831/jitp.v6.1.22280 


\section{Pendahuluan}

Perkembangan sains, teknologi informasi dan komunikasi (TIK) tidak terlepas atas dukungan dari berbagai ilmu pengetahuan, salah satunya adalah ilmu matematika. Amri (2016, p. 433) menjelaskan secara terminologi, TIK dapat dikelompokkan dalam dua aspek yaitu teknologi informasi dan teknologi komunikasi. Teknologi informasi didefinisikan sebagai segala hal yang berkaitan dengan proses, manipulasi teknologi, pengolahan, penyebaran data dan informasi dengan menggunakan hardware dan software, komputer, alat komunikasi, serta elektronik digital secara tepat dan efektif. Teknologi informasi disusun oleh teknologi komputer yang menjadi pendorong utama perkembangan teknologi informasi dan muatan informasi (information content) yang menjadi aplikasi informasi pada teknologi komputer. Teknologi komunikasi adalah segala sesuatu yang berkaitan dengan penggunaan alat bantu untuk memproses dan mentransfer data dari perangkat yang satu ke lainnya. Sebagai faktor utama, teknologi komunikasi adalah alat bantu penyebaran informasi, oleh karena itu, teknologi informasi dan teknologi komunikasi adalah dua buah konsep yang tidak terpisahkan.

Matematika memegang peranan yang luas pada berbagai bidang seperti sains, pendidikan, ilmu teknik, dan medis. Oleh karena itu, matematika dikenal sebagai induk ilmu pengetahuan. Ilmu matematika dapat membuat suatu model persamaan matematis sebagai bentuk pendekatan atas fenomena fisis yang terjadi. Tujuannya adalah mendapatkan solusi berupa formulasi matematika yang menjadi solusi atas permasalahan yang dihadapi. Salah satu bidang kajian ilmu matematika yang sering digunakan dalam bidang Matematika dan Ilmu Pengetahuan Alam (MIPA), teknik, dan kedokteran adalah penggunaan fungsi integral. Fungsi integral biasanya dibahas dalam mata kuliah kalkulus. Menurut Roza (2016, p. 1) matematika merupakan salah satu ilmu yang tidak dapat dipisahkan dari manusia, karena ilmu matematika membantu manusia dalam berbagai aspek kehidupan untuk memenuhi segala kebutuhan. Untuk kasus fisis yang semakin rumit, pendekatan fungsi integral akan menyesuaikan dengan tingkat kompleksitasnya, semakin kompleks fungsi integral dengan batas yang tinggi, maka perhitungan menjadi semakin banyak dan rumit. Perhitungan integral yang rumit ini membutuhkan tingkat konsentrasi dan ketelitian yang tinggi dalam perhitungannya. Pada Ilmu kedokteran tingkat keberhasilan harus 100\%, artinya tidak boleh terjadi kegagalan sekalipun.

Dalam bidang pendidikan khususnya pendidikan teknik dan pendidikan sains, mata kuliah kalkulus merupakan materi wajib yang harus diambil oleh setiap mahasiswa. Pada mata kuliah kalkulus khususnya materi integral, merupakan dasar untuk mengasah logika dan analisis bagi seseorang mahasiswa. Akan tetapi banyak mahasiswa yang gagal dan merasa sulit dalam mempelajari fungsi integral. Hal ini dikarenakan perlunya ketelitian dan analisis yang tepat pada fungsi integral. Padahal dalam dunia pendidikan fungsi integral sangat bermanfaat untuk: (1) Menentukan volume benda yang berbentuk abstrak, (2) Menetukan panjang sebuah kurva, (3) Memperkirakan jumlah populasi, dan (4) Menentukan surplus konsumen.

Kalkulus merupakan materi dalam rumpun kajian ilmu matematika. Sebagian besar mahasiswa dan peserta didik menganggap matematika dalah ilmu yang sulit untuk dipelajari, oleh karena itu beberapa peneliti mencoba riset untuk membuat teknologi dan strategi pembelajaran yang memudahkan dan meningkatkan pembelajaran matematika. Fitriani (2014, p. 244) dalam pengembangan risetnya berupa multimedia pembelajaran interaktif untuk meningkatkan kemampuan komunikasi dalam pembelajaran matematika, bahwa untuk mengembangkan multimedia pembelajaran interaktif terdapat beberapa langkah yang harus dilakukan yaitu concept, design, material, collecting, assembly, testing, 
dan distribution. Setelah dilakukan tahap uji coba diperoleh hasil bahwa sebagian besar mahasiswa atau sekitar $87 \%$ senang belajar menggunakan multimedia interaktif dalam meningkatkan kemampuan komunikasi dalam pembelajaran matematika. Selain itu, menurut Nasution dan Mukhtar (2016, p. 137) mengatakan bahwa hasil belajar matematika siswa yang diajarkan dengan strategi problem posing lebih tinggi dibandingkan dengan hasil belajar matematika siswa yang diajarkan dengan strategi pembelajaran ekspositori.

Rosyani dan Yunita (2018, p. 12) dalam penelitiannya yang mengembangkan aplikasi materi atau bahan ajar kalkulus berbasis android, memberikan simpulan bahwa: (1) Aplikasi materi bahan ajar android bermanfaat dan membantu mahasiswa untuk meningkatkan minat belajar khususnya mata kuliah kalkulus, (2) Aplikasi media belajar berbasis android ini sebagai alternatif pembelajaran yang inovatif, karena media berbasis android maka aplikasi dapat diakses kapanpun dan dimanapun dengan smartphone. Raharjo (2011, p. 180) mengkaji tentang pemanfaatan apliksi Software Course Lab V.2.4 untuk implementasi model pembelajaran interaktif problem solving pada mata kuliah matematika. Adapun hasilnya disimpulkan bahwa penerapan model problem solving dengan menggunakan software course lab versi 2.4 dapat meningkatkan kemampuan mahasiswa dalam mencapai kompetensi mata kuliah matematika.

Sistem pembelajaran untuk menghitung rumus bangun ruang dengan berbantuan komputer atau dengan istilah Computer Aided Instruction (CAI) bertujuan untuk mempermudah penyampaian materi matematika (Samsudin, 2017, p. 181). Computer Aided Insturction dapat membuat proses pembelajaran menjadi lebih efektif dan menarik. Sunismi dan Fathani (2017, p. 69) mengatakan bahwa perlu dikembangkan model pembelajaran yang dapat mengaktifkan mahasiswa, yaitu dengan model collaborative learning matematika melalui media blog dengan interactive digital book.
Sebagian besar peneliti melakukan penelitian lebih difokuskan pada strategi yang digunakan dalam proses pembelajaran dan masih sedikit penelitian yang mengkaji tentang pengembangan alat hitungnya. Padahal alat hitung ini dapat dikategorikan sebagai sebuah invention dalam teknologi pendidikan. Pengembangan alat hitung ini dapat dikembangkan dengan bahasa pemrograman dan menggunakan perangkat teknologi informasi. Oleh karena itu, perlu adanya solusi atas permasalahan dalam kegiatan perkuliahan tersebut.

Mengacu pada perkembangan teknologi saat ini, banyak bahasa pemrograman yang dapat digunakan untuk mengembangkan aplikasi penyelesaian perhitungan integral dengan mempertimbangkan akurasi dan fleksibilitasnya. Akurasi berhubungan dengan ketepatan hasil perhitungan yang dihasilkan, sedangkan fleksibilitasnya terkait dengan kemampuan berjalan pada software dan hardware yang ada. Peneliti mencoba melakukan riset untuk menjawab dan memberikan sebuah solusi atas perhitungan integral yang banyak dan rumit, yaitu dengan mengembangkan aplikasi dengan menggunakan bahasa Hypertext Markup Language (HTML) dan JavaScript. Hal terebut bertujuan untuk memudahkan pengguna dalam mengoperasikan serta menjalankan aplikasi yang dikembangkan karena aplikasi hanya memerlukan web browser dalam menjalankannya. Aplikasi yang peneliti kembangkan juga memiliki tingkat fleksibilitas yang tinggi, karena dapat berjalan pada berbagai operating system serta dapat bekerja pada berbagai hardware atau platform, seperti: smartphone, personal computer, dan laptop.

Tujuan utama dari penelitian ini adalah merancang sebuah aplikasi yang dapat menghitung fungsi integral secara akurat serta memiliki fleksibilitas yang tinggi. Tingkat keakuratan perhitungan menjadi target utama dalam mengembangkan sebuah aplikasi perhitungan integral, oleh karenanya pemilihan metode numerik yang tepat sangat diperlukan sebagai dasar bagaimana sistem bekerja. 
Berdasarkan analisis yang telah dilakukan, peneliti menggunakan metode Simpson $1 / 3$ sebagai dasar perhitungan integral. Metode ini dapat memberikan galat sama dengan 0 (nol) untuk $\mathrm{n}$ (iterasi) yang tinggi. Hasil akhir dari penelitian ini adalah sebuah webbased application yang berfungsi untuk menghitung persamaan integral, yang dapat dijalankan pada semua Operating System dan semua platform.

Persoalan integrasi numeric merupakan perhitungan secara numeric integral tentu. Dalam hal ini dimisalkan $a$ dan $b$ merupakan batas-batas integrasi, $\mathrm{f}$ adalah fungsi yang dapat diberikan secara eksplisit dalam bentuk persamaan atau secara empirik dalam bentuk tabel nilai (Munir, 2013, p. 267). Terdapat tiga pendekatan dalam menurunkan rumus integrasi numeric. Adapun pendekatan tersebut meliputi tafsiran geometri intergral tentu, polinom interpolasi, dan tidak menggunakan titik diskrit sama sekali. Rumus integrasi numeric dapat dilihat pada Rumus 1.

$$
I=\int_{a}^{b} f(x) d x
$$

Metode perhitungan integral secara numeric bekerja dengan sejumlah titik diskrit. Untuk hampiran nilai integrasi yang lebih baik, dapat ditingkatkan dengan polinom interpolasi berderajad lebih tinggi. Misalkan fungsi $f(x)$ dihampiri dengan polinom interpolasi derajad 2 yang grafiknya berbentuk parabola. Luas daerah yang dihitung sebagai hampiran nilai integrasi adalah daerah di bawah parabola untuk itu dibutuhkan 3 buah titik data.

Mengacu pada Gambar 1, kurva fungsi sepanjang integrasi $[a, b]$ dibagi menjadi $\mathrm{n}+1$ buah titik diskrit $\mathrm{x}_{0}, \mathrm{x}_{1}, \mathrm{x}_{2}, \ldots . \mathrm{x}_{\mathrm{n}}$ dengan $\mathrm{n}$ genap, setiap tiga buah titik akan didekati dengan kurva parabola, maka akan mempunyai $\mathrm{n} / 2$ potongan parabola. Bila masing-masing polinom berderajad 2 tersebut diintegralkan di dalam sub interval integrasinya, maka jumlah integral tersebut membentuk kaidah Simpson 1/3 Gabungan
(Munir, 2013, p. 284). Adapun bentuk persamaannya dapat dilihat pada Rumus 2.

$I \approx \frac{h}{3}\left(f_{0}+4 \sum_{n=1,3, . .}^{n-1} f i+2 \sum_{n=2,4, . .}^{n-2} f i+f_{n}\right)$

Hypertext Markup Language (HTML) adalah bahasa standar yang digunakan untuk menampilkan konten pada halaman website. Fungsi-fungsi yang dapat dilakukan dengan bahasa programan HTML adalah: (1) Mengatur serta mendesain tampilan isi halaman website, (2) Membuat tabel pada halaman website, (3) Mempublikasikan halaman website secara online, (4) Membuat form yang dapat menjadi input serta menangani registrasi dan transaksi via website, (5) Menampilkan area gambar pada browser.

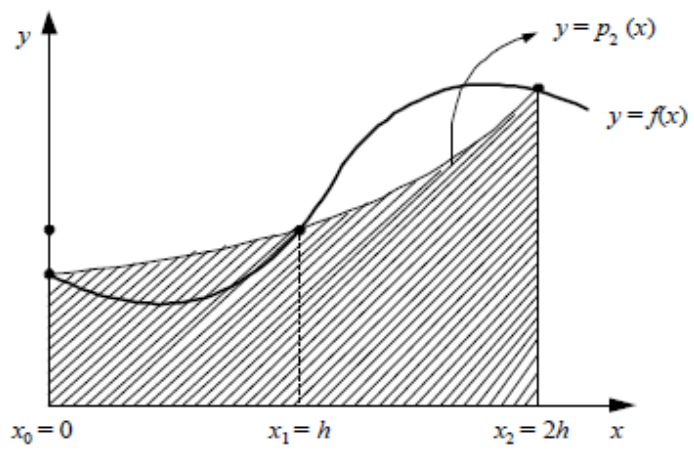

Gambar 1. Kurva Kaidah Simpson 1/3

Penanda perintah pada bahasa pemrograman Hypertext Markup Language (HTML) disebut dengan tag. Tag digunakan untuk menentukan tampilan dari dokumen HTML. Tag HTML berfungsi untuk mendefinisika bahwa isi dalam file tersebut adalah dokumen. Element head merupakan kepala dari dokumen HTML. Elemen head digunakan untuk menempatkan identitas file, sedangkan tag body digunakan untuk menentukan konten yang akan ditampilkan pada halaman website (Hidayatullah \& Kawistara, 2015, pp. 13-15). Struktur dari pemrograman HTML dapat dilihat pada Gambar 2. 


$$
\begin{aligned}
& <\text { html> } \\
& <\text { head }>\text {.... </head }> \\
& <\text { body> } \\
& </ \text { body }> \\
& </ \text { html }>
\end{aligned}
$$

Gambar 2. Struktur program HTML

JavaScript adalah bahasa pemrograman berbentuk kumpulan script yang berjalan pada suatu dokumen HTML (Lavarino \& Yustanti, 2016, p. 74). JavaScript dapat menyempurnakan tampilan dan sistem pada halaman web-based application yang dikembangkan. Adapun karakteristik dari bahasa pemrograman JavaScript adalah: (1) Bahasa permrograman berjenis high-level programing; (2) Bersifat client-side; (3) Berorientasi pada objek, dan (4) Bersifat loosely typed. Aplikasi atau tools standar yang digunakan dalam mengimplementasikan JavaScript adalah: (1) Software text-editor: seperti Notepad++, Adobe Dreamweaver dan NetBeans; (2) Web browser, seperti: Mozilla Firefox, Google Chrome, Internet Explorer, OperaMini, Safari, dan lain sebagainya; (3) HTML. Kelemahan dari bahasa pemrograman JavaScript ini sendiri adalah JavaScript tidak didukung oleh browser versi lama (Enterprise, 2017, pp. 1-3).

\section{Metode Penelitian}

Kurniawan, Holisin dan Kristanti (2017, pp. 131) Metode merupakan sarana dalam pencapaian tujuan penelitian yang digunakan oleh peneliti, sehingga penggunaan metode ini disesuaikan dengan masalah dan tujuan penelitian. Metode penelitian adalah cara ilmiah untuk memperoleh data dengan kegunaan dan tujuan tertentu. Penelitian yang dilakukan oleh peneliti dalam perancangan web aplikasi ini merupakan jenis penelitian Research and Development (RED).

Pendanaan penelitian ini berasal dari hibah Ristek Dikti yang masuk dalam kategori Penelitian Dosen Pemula (PDP). Sesuai dengan kontrak penelitian, maka penelitian ini dilaksankan mulai bulan Mei sampai dengan Oktober 2018. Sedangkan lokasi penelitian bertempat di Laboratorium Latihan Keterampilan Manajemen Mahasiswa (LKMM) Uninversitas Indraprasta Persatuan Guru Repubilk Indonesia (PGRI). Kegiatan penelitian sebagian besar adalah pembuatan pengkodean/scripting dengan Hypertext Markup Language dan JavaScript.

Subjek dalam penelitian ini adalah ahli informatika (media), ahli matematika (materi), dosen dan mahasiswa. Tahapan proses penelitian dapat dilihat pada Gambar 3. Dikarenakan jenis penelitian ini adalah penelitian $R \mathcal{E} D$, maka ujicoba terhadap produk penelitian adalah tahap paling penting. Kelayakan pada penelitian ini meliputi kelayakan proses dan kelayakan hasil. Desain penelitian yang cocok untuk untuk menilai kelayakan produk penelitian yang sedang direkomendasikan dalam uji coba produk penelitian ini adalah eksperimental.

Prosedur pada penelitian Research and Development ini melalui serangkaian proses sebagai berikut: (1) Perencanaan, meliputi: mendefinisikan bidang/ruang lingkup, mengidentifikasi karakteristik peserta didik, membuat dokumen perencanaan, menentukan dan mengumpulkan sumber, melakukan brainstorming; (2) Perancangan, meliputi: melakukan analisis konsep dan cakupan materi, membuat flowchart, mengembangkan layout, mengumpulkan sumber konten atau isi, menentukan software yang akan digunakan; (3) Pengembangan, meliputi: perancangan website dengan domain dan hosting, mengembangkan konten teks, menggabungkan bagian dari konten audio, video, animasi, serta teks, menyiapkan materi pendukung, hingga $e$-learning siap untuk digunakan saat uji alfa (Irawan \& Surjono, 2018, p. 7). 
TAHAP 1

TAHAP 2

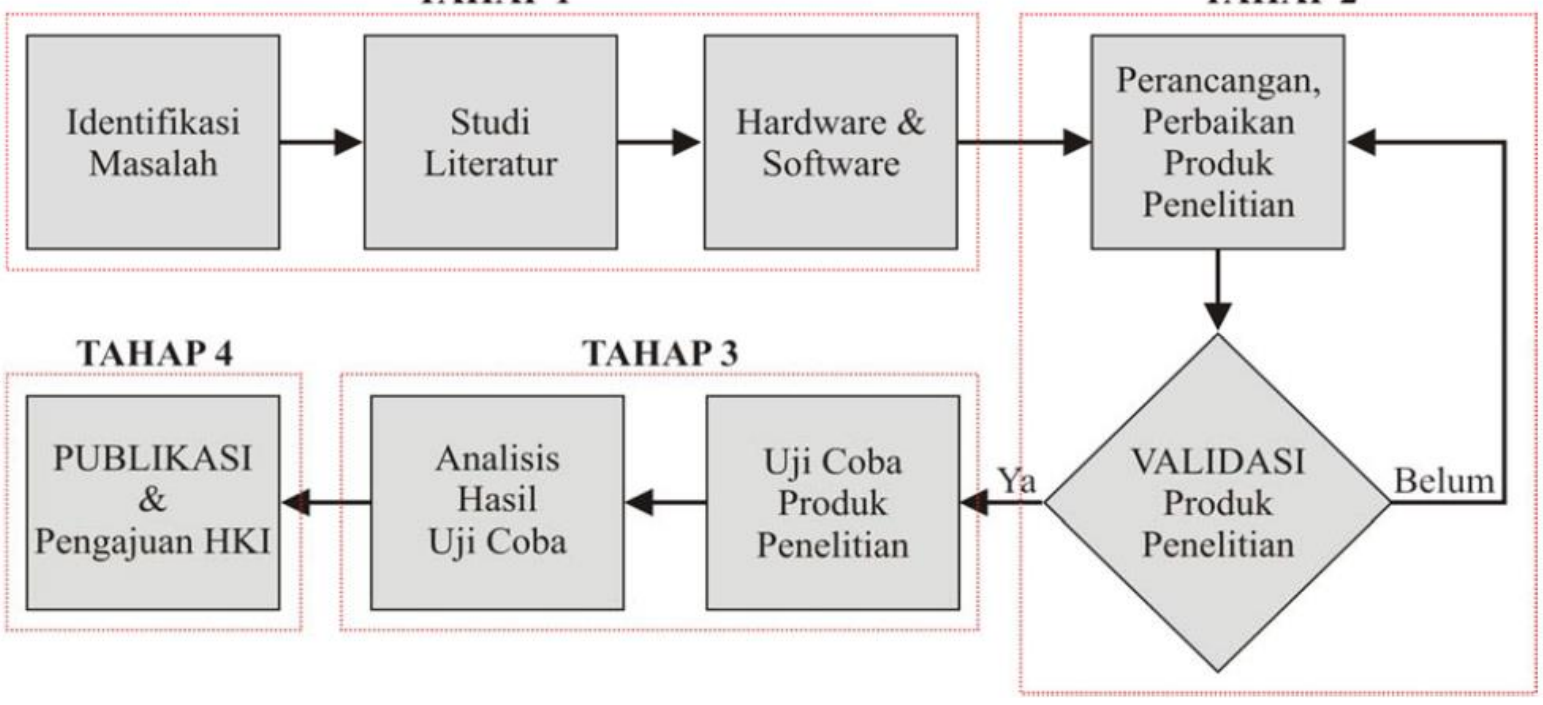

Gambar 3. Diagram Alir Penelitian

\section{Hasil dan Pembahasan}

Produk dari penelitian ini adalah aplikasi yang berfungsi untuk menghitung fungsi integral pada mata kuliah kalkulus. Menurut Mason dan Rennie (2009, p. 140) aplikasi/software merupakan pemrograman komputer atau seperangkat instruksi yang terorganisasikan untuk selalu dirancang membuat perangkat elektronik bekerja seperti yang diinginkan atau sebagaimana fungsinya. Software biasanya dipasangkan dengan infrastruktur fisik lainnya, yaitu hardware. Aplikasi khas software antara lain program-program umum komputer yang digunakan untuk melakukan wordprocessing, kompilasi database, atau menkoneksikan ke internet untuk email atau melakukan surfing. Aplikasi yang peneliti kembangkan bekerja menggunakan web browser karena dirancang dengan menggunakan bahasa pemrograman HTML dan JavaScript. Untuk mempopulerkan aplikasi tersebut peneliti memberikan nama Integral Calculator. Terdapat 3 fungsi menu pada aplikasi yang dirancang, yaitu fungsi menu pada halaman awal/home, halaman menu utama, dan halaman hasil perhitungan.

Gambar 4 merupakan tampilan awal/home dari web-based application. Pada bagian ini terdapat logo aplikasi dan versi- nya. Untuk versi akan selalu berubah, dikarenakan peneliti ke depannya akan mengembangkan web-based application tersebut dengan tambahan fitur dan fungsi. Selain itu, terdapat 2 tombol About Us dan Start Now pada tampilan halaman awal aplikasi. Tombol About Us berfungsi untuk melihat info dari pengembang/peneliti, sedangkan tombol Start Now berfungsi untuk masuk ke halaman menu input.

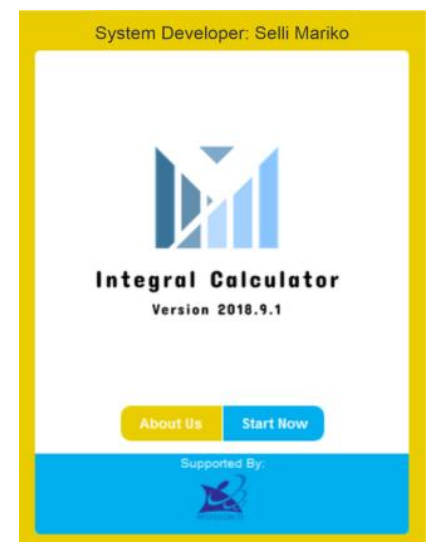

Gambar 4. Tampilan Halaman Awal/Home

Gambar 5 merupakan tampilan menu utama. Halaman menu utama berfungsi untuk melakukan input nilai terhadap semua parameter fungsi integral 
yang akan dihitung. Adapun parameter fungsi integral yang akan dihitung adalah:

a : batas bawah integarsi

b : batas atas integrasi

$\mathrm{n} \quad$ : jumlah pias integrasi

$\mathrm{f}(\mathrm{x})$ : input nilai konstanta variabel

Pada halaman manu utama terdapat 2 tombol yaitu tombol hitung dan tombol reset. Tombol hitung berfungsi untuk melakukan kalkulasi terhadap parameter yang sudah dimasukkan. Sedangkan tombol reset berfungsi untuk menghapus semua parameter yang sudah dimasukkan ke dalam aplikasi. Apabila pengguna atau user mengalami kesulitan dalam menggunakan software, user dapat menggunakan fitur tautan/link klik disini, maka secara otomatis akan muncul petunjuk penggunaan software.

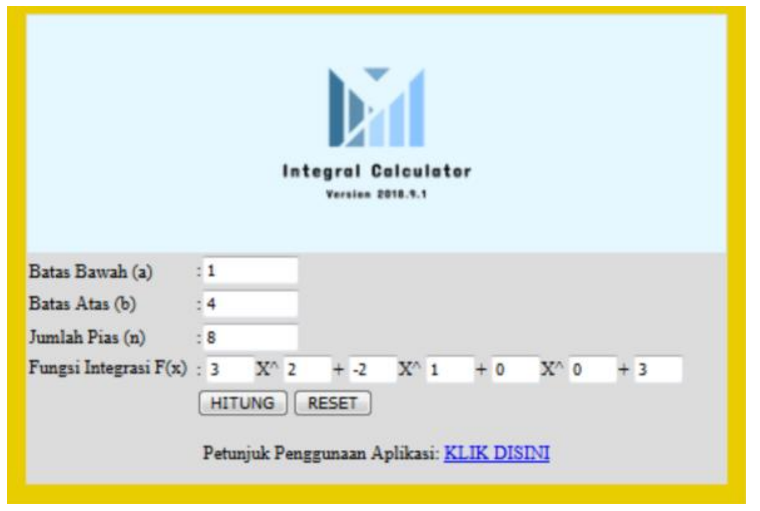

Gambar 5. Tampilan Halaman Menu Utama

Pada Gambar 6, merupakan tampilan halaman hasil perhitungan. Hasil perhitungan yang ditampilkan oleh aplikasi ini adalah: (1) Deskripsi fungsi integral, menjelaskan secara umum tentang gambaran berbagai nilai variabel dan konstanta yang akan dihitung; (2) Hasil perhitungan integrasi, menampilkan hasil pada proses setiap iterasi. Setiap iterasi akan dihitung berdasarkan jumlah pias integrasi yang dimasukkan; dan (3) Nilai hasil integrasi numerik, menunjukkan nilai akhir/harga mutlak hasil perhitungan nilai integrasi numerik.

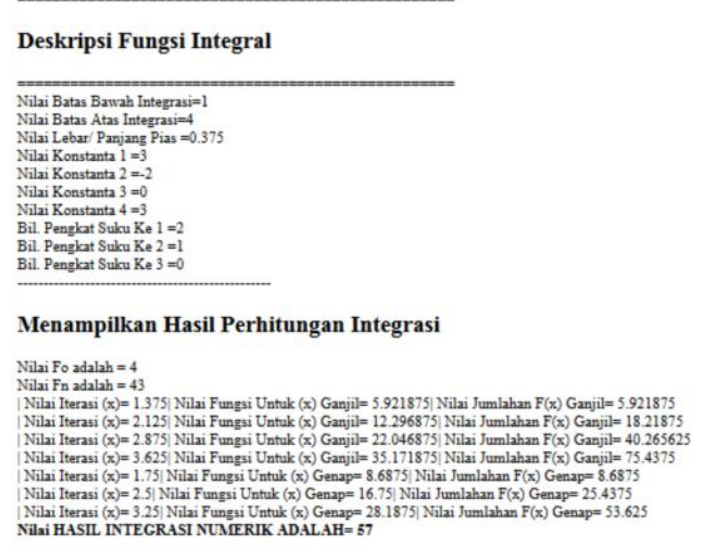

Gambar 6. Tampilan Halaman Hasil Perhitungan

Sebagai bahan kelayakan atas produk yang dihasilkan pada Skim Penelitian Dosen Pemula, maka dilakukan validasi oleh para ahli. Tim peneliti menggunakan ahli materi dan ahli media untuk melakukan validasi atas produk peneliltian yang dikembangkan. Sebagai pakar atau ahli dalam bidang materi, maka peneliti menggunakan pakar matematika sedangkan validator produk/media peneliti menggunakan ahli informatika. Dalam validasi produk penelitian ini, dilakukan sabagai cara untuk mendapatkan informasi apakah produk tersebut layak atau tidak untuk digunakan. Selain itu menjawab apakah hasil pengukuran sudah tepat dengan variabel yang diukur.

Tabel 1. Hasil Uji Validasi

\begin{tabular}{lcccl}
\hline \multicolumn{1}{c}{ Aspek } & $\begin{array}{c}\text { Skor } \\
\text { Aktual }\end{array}$ & $\begin{array}{c}\text { Skor } \\
\text { Ideal }\end{array}$ & $\begin{array}{c}\text { \% Skor } \\
\text { Aktual }\end{array}$ & Kriteria \\
\hline Functionality & 80 & 90 & 88,89 & Sngt Baik \\
Reliability & 40 & 50 & 80,00 & Baik \\
Useability & 73 & 80 & 91,25 & Sngt Baik \\
Efficiency & 30 & 30 & 100,00 & Sngt Baik \\
Total & $\mathbf{2 2 3}$ & $\mathbf{2 5 0}$ & $\mathbf{9 0 , 0 3}$ & Sngt Baik \\
\hline
\end{tabular}

Mengacu pada Tabel 1 dari hasil perhitungan yang diperoleh dari skor validator pada aspek functionality, usability dan efficiency, masuk ke dalam kriteria sangat baik. Pada aspek reliability termasuk dalam kategori baik, sehingga dapat ditarik 
kesimpulan bahwa aplikasi perhitungan integrasi numerik berbasis JavaScript dan HTML termasuk ke dalam kategori aplikasi sangat baik.

Setelah aplikasi dinyatakan layak oleh validator, maka langkah selanjutnya adalah melakukan uji coba. Uji coba dilakukan pada 38 orang mahasiswa dan 2 orang dosen. Peneliti membuat soal terkait materi integral kemudian mahasiswa dan dosen mengerjakan dengan aplikasi yang telah dikembangkan. Dari hasil uji coba tersebut, aplikasi dapat berjalan $100 \%$ pada berbagai tipe platform, seperti laptop, smartphone, dan personal computer, serta berbagai operating system. Selain itu lebih dari $90 \%$ responden dapat mengoperasikan aplikasi tersebut dengan lancar.

Melalui hasil instrumen uji coba dan wawancara dengan responden, peneliti mendapatkan informasi tentang tanggapan terhadap produk penelitian berupa webbased application untuk menghitung fungsi integral. Hasil instrumen uji coba dan wawancara dengan responden dapat disimpulkan sebagai berikut: (1) Tampilan fitur-fitur yang terdapat pada produk penelitian/web-based application dirasakan sangat user friendly, sehingga aplikasi mudah untuk digunakan dan dioperasikan, (2) Instalasi aplikasi/produk penelitian sangat mudah. Hal ini dikarenakan untuk menjalankan aplikasi hanya perlu copy and paste saja dan dibuka melalui web browser, (3) Aplikasi/produk penelitian memiliki kinerja yang tinggi, namun saat memproses data tidak membebani kinerja smartphone, sehingga tidak terjadi crash saat software dijalankan, (4) Software sangat efektif untuk menghitung persamaan integral yang rumit; serta (5) Perhitungan dilakukan sangat cepat dan hasil yang akurat.

Pada prinsipnya, aplikasi alat hitung berupa web-based application perhitungan fungsi kalkulus bukan untuk mengurangi aktivitas belajar mahasiswa di kelas. Pengetahuan dan materi kalkulus pada dasarnya harus dikuasai oleh setiap siswa. Hal ini dikarenakan setiap mahasiswa yang mengikuti mata kuliah kalkulus wajib menguasai standar kompetensi yang diwajibkan. Menurut Mariani \& Wardono (2018, p. 13), proses pembelajaran matematika harus melibatkan mental siswa secara aktif. Kegiatan mental untuk pembelajaran ini sangat sulit dilihat/diobservasi kecuali bila kegiatan pembelajaran tersebut diikuti dengan kegiatan fisik, kegiatan fisik yang terlihat tidak selalu menunjukkan keterlibatan aktivitas mental dalam berpikir matematika. Jadi, dapat dikatakan bahwa aplikasi ini selayaknya digunakan hanya untuk mempermudah, membantu, dan melakukan cross-check atas hasil perhitungan fungsi integral yang telah dilakukan user.

Untuk mencapai tujuan kegiatan pembelajaran matematika, khususnya materi kalkulus perlu adanya sinergi dalam prosesnya. Menurut Koderi (2017, p. 219) teknologi terpadu adalah cara memproduksi dan menyampaikan bahan ajar dengan memadukan beberapa jenis media yang dikendalikan oleh komputer. Teknologi terpadu merupakan hasil dari penggabungan unsur-unsur yang terdapat dalam media cetak dengan komputer. Jadi dalam pembelajaran kalkulus peran teknologi digunakan untuk menunjang aktivitas guru dan dosen dalam menyampaikan materi pembelajaran.

Produk penelitian ini merupakan inovasi baru dalam teknologi pendidikan. Akan tetapi guru maupun dosen memiliki peran yang paling utama dalam memberikan materi untuk mencapai kompetensi yang diinginkan. Guru dan dosen harus cermat dalam menggunakan teknologi untuk mendesain dan melakukan bimbingan program belajar. Teknologi ini dipergunakan untuk mempermudah perhitungan integral yang cukup rumit. Mason dan Rennie (2009, p. 124) mengemukakan bahwa tolok ukur kualitas untuk desain program belajar terfokus pada hasil pembelajaran yang sudah dinyatakan dan cara isi program belajar mengalir dari hasil pembelajaran. Demikian pula, proses assesment harus mencerminkan semua hasil pembelajaran yang memberikan pena- 
waran berupa kesempatan bagi mahasiswa untuk menunjukkan penguasaan masingmasing mata kuliah. Selain itu ada atribute penting yang dipersyaratkan, yakni: minat, kemauan dan kemampuan berinteraksi baik kepada sesama mahasiswa maupun dengan dosenya.

Setiap hasil penelitian pasti akan memberikan penemuan yang baru. Penemuan teknologi pendidikan yang berbasis perangakat IT ini pasti memiliki beberapa dampak terhadap dunia pendidikan khususnya pada saat persiapan, proses dan penilaian pada kegiatan pembelajaran. Menurut Jamun (2018, pp. 50-51) dampak positif dari hasil penelitian teknologi terhadap pendidikan meliputi: (1) Sebagai sumber ilmu dan pusat pendidikan, (2) Munculnya metode pembelajaran yang baru serta memudahkan siswa dan guru dalam proses pembelajaran, (3) Adanya sistem pengolahan data hasil penilaian menggunakan perangkat teknologi informasi, dan (4) Pemenuhan kebutuhan akan fasilitas pendidikan dapat dipenuhi dengan cepat. Dalam bidang pendidikan tentu banyak hal dan bahan yang harus dipersiapkan, misalkan untuk memenuhi kebutuhan akan jumlah soal yang banyak tentu membutuhkan waktu yang lama untuk mengerjakannya jika dilakukan secara manual.

Menurut Husaini (2014, p. 24), ada beberapa langkah pemanfaatan teknologi informasi dalam proses pendidikan, yaitu: (1) Merancang dan membuat aplikasi database, yang menyimpan dan mengolah data dan informasi akademik, baik sistem perkuliahan, sistem penilaian, informasi kurikulum, manajemen pendidikan, maupun materi pembelajaran; (2) Merancang dan membuat aplikasi pembelajaran berbasis portal, webiste, multimedia interaktif, yang terdiri atas aplikasi tutorial dan learning tool; (3) Mengoptimalkan pemanfaatan media televisi edukasi sebagai materi pengayaan dalam rangka menunjang peningkatan mutu pendidikan, dan (4) mengimplementasikan sistem secara bertahap mulai dari lingkup yang lebih kecil hingga meluas, sehingga memudahkan manajemen pemanfaatan TI dalam proses penyelenggaraan pendidikan.

Pemanfaatan teknologi informasi sebagai media pembelajaran dapat melalui pemanfaatan internet dalam e-learning maupun penggunaan komputer sebagai media interaktif. Diharapkan dengan penggunaan media ini, dapat merangsang pikiran, perasaan, minat serta perhatian peserta didik sehingga proses pembelajaran dapat berlangsung dengan baik. Selain itu, proses pembelajaran akan semakin efektif karena penggunaan media pembelajaran memungkinkan teratasinya hambatan dalam proses komunikasi antara guru dengan peserta didik seperti hambatan fisiologis, psikologis, kultural, dan lingkungan.

Berdasarkan pandangan dari beberapa ahli tersebut maka dapat ditarik sebuah konklusi tentang manfaat produk penelitian skim penelitian dosen pemula ini dalam bidang pendidikan. Produk penelitian ini memberikan manfaat untuk membantu guru, dosen dan mahasiswa dalam proses/kegiatan pembelajaran serta dalam mempercepat pengolahan data untuk mendapatkan hasil perhitungan yang cepat dan akurat. Selain itu dapat juga digunakan sebagai bahan komparasi atas perhitungan manual.

Produk penelitian ini memiliki dampak positif sebagai bentuk manfaat atas inovasi yang dihasilkan, ada pula dampak negatif yang muncul sebagai bentuk kerugiannya. Oleh karena itu, perlu adanya cara untuk menanggulangi dampak negatif tersebut. Menurut Ratnaya (2011, p. 25) kemajuan teknologi informasi tidak mungkin ditolak tetapi harus dapat dimanfaatkan agar tidak tersisih dari tata pergaulan masyarakat dunia. Salah satu jalan agar teknologi informasi dapat dimanfaatkan adalah dengan memberdayakan masyarakat karena semakin tidak berdaya masyarakat, maka dampak negatif akan muncul dan merusak kehidupan. Pemberdayaan masyarakat dapat dilakukan dengan cara: (1) Mengenalkan tekologi informasi sekaligus manfaatnya bagi kehidupan sosial 
kemasyarakatan; (2) Menghilangkan gagap teknologi dan rasa minder dalam mensikapi teknologi infomasi; (3) Mengenalkan dan mengingatkan masyarakat kemungkinan dampak negatif yang dapat muncul dalam pemanfaatan tekno-logi informasi; serta (4) Meningkatkan daya nalar dan daya seleksi masyarakat terhadap berbagai informasi yang membanjir, sehingga masyarakat semakin kritis dan dewasa dalam menyikapinya.

Sekolah sebagai tempat menimba ilmu juga perlu memberikan peran penanggulangan dampak negatif terhadap hasil penelitian yang berhubungan dengan perkembangan teknologi informasi dan komunikasi. Menurut Rahman (2016, p. 31) sekolah sebagai pusat pendidikan bagi siswa dalam rangka menimba pengetahuan, keterampilan seni budaya, olahraga serta meningkatkan budi pekerti yang luhur, untuk ini diperlukan sarana dan prasarana yang memadai serta perlu diciptakan lingkungan yang bersih, sehat, tertib serta aman agar dapat menunjang keberhasilan pendidikan belajar mengajar. Guru adalah orangtua siswa di sekolah, oleh karena itu perlu adanya sikap berdialog antara guru dengan siswa tentang berbagai hal, khususnya tentang masalah dalam proses belajar mengajar, agar tujuan pembelajaran dapat tercapai.

Mengacu pada pendapat ahli atas penanggulangan dampak negatif dari perkembangan teknologi informasi dan komunikasi pada dunia pendidikan, maka peneliti mengambil beberapa pernyataan yang dapat digunakan untuk menanggulangi dampak negatif atas hasil produk penelitian ini. Adapun simpulan bagaimana mengatasi dampak negatif atas hasil penelitian pada skim Penelitian Dosen Pemula (PDP) ini meliputi: (1) Memanfaatkan produk penelitian dengan bijaksana dan meningkatkan daya nalar serta kemampuan terhadap materi yang diajarkan; (2) Menggunakan produk penelitian sebagai sarana yang berfungsi untuk memudahkan dalam menimba ilmu pegetahuan; (3) Memotivasi siswa maupun mahasiswa dalam belajar dan taat pada aturan dalam pemanfaatan pernagkat teknologi informasi dan komunikasi.

\section{Simpulan}

Mengacu pada tujuan penelitian, maka dapat disimpulkan bahwa sudah telah dihasilkannya produk penelitian berupa software web-based application untuk menghitung fungsi integral. Aplikasi ini sudah layak untuk digunakan dan tidak ada masalah pada saat digunakan. Aplikasi ini sangat fleksibel, karena dapat berfungsi dan dioperasikan pada berbagai tipe operating system dan berbagai macam platform (smartphone, personal computer dan laptop). Produk penelitian ini merupakan inovasi yang baru dalam bidang teknologi pendidikan. Hal ini dikarenakan belum ada produk sejenis yang dapat menghitung fungsi integrasi numerik.

Adapun manfaat produk penelitian ini, yaitu: (1) Produk penelitian ini membantu guru, dosen dan mahasiswa dalam proses/kegiatan pembelajaran khususnya dalam menghitung fungsi integral, (2) Produk penelitian ini bermanfaat dalam mempercepat pengolahan data dan formulasi integrasi numerik yang banyak untuk mendapatkan hasil perhitungan yang cepat dan akurat, (3) Produk penelitian ini dapat digunakan sebagai bahan komparasi atas perhitungan manual dengan tujuan untuk mengecek apakah perhitungan secara manual telah memperoleh hasil yang sesuai atau belum. Sebagai bahan penyempurnaan atas produk yang dihasilkan, maka peneliti ke depannya akan mengembangkan fiturfitur tambahan untuk menyelesaikan kasus da-lam mata kuliah kalkulus seperti: (1) Inte-gral lipat dua, (2) Integral lipat tiga, dan (3) Penyelesaian fungsi differensial dan tri-gonometri.

\section{Terima Kasih}

Peneliti mengucapkan terima kasih yang sebesar-besarnya kepada: Direktorat Riset dan Pengabdian Masya- 
rakat, Direktorat Jenderal Penguatan Riset dan Pengembangan, Kementrian Riset, Teknologi dan Perguruan Tinggi Sesuai dengan Surat Kontrak Penelitian T.A. 2018 Nomor: 032/KM/PNT/2018, Tanggal 06 Maret 2018. yang sudah memberikan support berupa pendanaan kegiatan penelitian pada skim Penelitian Dosen Pemula, (2) Lembaga Penelitian dan Pengabdian Masyarakat Universitas Indraprasta PGRI yang sudah membantu memfasilitasi pengajuan proposal, monitoring dan evaluasi serta pendampingan pada saat pelaporan hasil penelitian.

\section{Daftar Pustaka}

Amri, A. (2016). Analisis pemanfaatan teknologi informasi dan komunikasi dalam menunjang terwujudnya Makassar sebagai "smart city". Jurnal Komunikasi KAREBA, 5(2), 431-445. doi:http://dx.doi.org/10.31947/kji k.v5i2.1916.

Enterprise, J. (2017). Otodidak pemrograman JavaScript. Jakarta: Elex Media Komputindo.

Fitriani, A. D. (2014). Pengembangan multimedia interaktif dalam pembelajaran geometri untuk meningkatkan kemampuan komunikasi calon guru Sekolah Dasar. Jurnal Teknologi Pendidikan EDUTECH, 1(2), 236-245. doi:http://dx.doi.org/10.17509/ed utech.v13i2.3105.

Hidayatullah, P., \& Kawistara, J. K. (2015). Pemrograman web. Bandung: Informatika.

Husaini, M. (2014). Pemanfaatan teknologi informasi dalam bidang pendidikan (e-education). MIKROTIK: Jurnal Manajemen Informatika, 2(1).

Irawan, R., \& Surjono, H. D. (2018). Pengembangan e-learning berbasis moodle dalam peningkatkan pemahaman lagu pada pembelajaran bahasa Inggris. Jurnal Inovasi Teknologi Pendidikan, 5(1), (111).

doi:https://doi.org/10.21831/jitp.v 5i1.10599.

Koderi, K. (2017). Pengembangan modul elektronik berbasis SAVI untuk pembelajaran bahasa Arab. JTPJurnal Teknologi Pendidikan, 19(3), 206-223.

doi:https://doi.org/10.21009/JTP1 903.4 .

Kurniawan, A., Holisin, I., \& Kristanti, F. (2017). Aplikasi persamaan deferensial biasa model eksponensial dan logistik pada pertumbuhan penduduk kota Surabaya. MUST: Journal of Mathematics Education, Science and Technology, 2(1), 129-141. doi:http:/ / dx.doi.org/10.30651/mu st.v2i1.529.

Mariani, S., \& Wardono, W. (2018). IbM guru-guru matematika SMP yang mengalami kesulitan pemecahan masalah melalui visualisasi geometri analitik bidang cartesius berbantuan software geometer's sketchpad. REKAYASA: Jurnal Penerapan Teknologi dan Pembelajaran. 16(1), (11-22). doi:http:/ / dx.doi.org/10.15294/rek ayasa.v16i1.15079.

Mason, R., \& Rennie, F. (2009). E-learning panduan lengkap memahami dunia digital dan internet. Yogyakarta: Pustaka Baca.

Munir, R. (2013). Metode Numerik. Bandung: Informatika.

Nasution, H. \& Muhktar, M. (2016). Pengaruh strategi pembelajaran dan kreativitas terhadap hasil belajar matematika siswa Sekolah Usaha Perikanan Menengah Negeri Pariaman. Jurnal Teknologi Pendidikan, 9(2), 127-138. 
doi:https://doi.org/10.24114/jtp.v9 i2.4901.

Raharjo, N. E. (2011). Aplikasi software course lab v.2.4 untuk implementasi model pembelajaran interactive problem solving pada kuliah matematika. Jurnal Pendidikan Teknologi dan Kejuruan, 20(2), 173180.

doi:https://doi.org/10.21831/jptk. v20i2.3315.

Rahman, A. (2016). Pengaruh negatif era teknologi informasi dan komunikasi pada remaja (perspektif pendidikan islam). Al-Ishlah: Jurnal Studi Pendidikan, 14(1), 18-35.

Ratnaya, I. G. (2011). Dampak negatif perkembangan teknologi informatika dan komunikasi dan cara antisipasinya. JPTK: Jurnal Pendidikan Teknologi dan Kejuruan, UNDIKSHA, 8(1), 17-28. doi:http://dx.doi.org/10.23887/jpt k-undiksha.v8i1.2890.

Rosyani, P., \& Yunita, D. (2018).

Pengembangan aplikasi bahan ajar kalkulus 1 berbasis android. Jurnal
Informatika Universitas Pamulang, 3(3), 8-13.

Roza, M. (2016). Pengaruh model pembelajaran kooperatif tipe stad melalui teknik quick on the draw terhadap kemampuan komunikasi matematis siswa kelas VII SMPN 3 Talamau Kabupaten Pasaman Barat. E-Tech: Jurnal Ilmiah Teknologi Pendidikan, 1(1), 1-11. doi:https://doi.org/10.24036/et.v2i 1.10467

Samsudin, S. (2017). Aplikasi computer aided instruction (CAI) dalam pembelajaran matematika bangun ruang. Jurnal Teknik Informatika, 10(2), 169-182.

doi:https://doi.org/10.15408/jti.v1 0i2.6995.

Sunismi, S., \& Fathani, A. H. (2017). Prototipe model collaborative learning matematika melalui media blog dengan interactive digital book mata kuliah kalkulus II. Jurnal Fourier: Jurnal Matematika dan Pembelajaran, 6(2), 69-83. doi:https://doi.org/10.14421/fourier.20 17.62.69-83. 